\title{
HUBUNGAN DINAMIK ANTARA PASARAN SAHAM DENGAN KADAR PERTUKARAN: BUKTI EMPIRIKAL DI ASEAN-3
}

\section{DYNAMIC RELATIONSHIP BETWEEN STOCK MARKET AND EXCHANGE RATE: EMPIRICAL EVIDENCE IN ASEAN-3}

\author{
ABU HASSAN SHAARI MOHD NOR \\ MORI KOGID \\ TAMAT SARMIDI \\ Fakulti Ekonomi dan Pengurusan \\ Universiti Kebangsaan Malaysia
}

\begin{abstract}
Abstrak
Tujuan utama kajian ini adalah untuk menentukan hubungan antara pasaran saham dengan kadar pertukaran di negara ASEAN terpilih iaitu Malaysia, Thailand dan Filipina. Dengan menggunakan data bulanan bermula Januari 1994 hingga September 2011, hasil ujian Johansen dengan perubahan struktur menunjukkan wujud hubungan kointegrasi antara pasaran saham dengan kadar pertukaran bagi kes Malaysia dan Filipina sahaja. Walau bagaimanapun, hasil ujian penyebab Granger jangka pendek berdasarkan pendekatan dinamik VECM dan Toda-Yamamoto menunjukkan wujud hubungan penyebab dua hala antara pasaran saham dengan kadar pertukaran bagi kes Malaysia dan Thailand dengan darjah hubungan penyebab Granger yang kuat daripada kadar pertukaran kepada pasaran saham di Malaysia. Sebaliknya tiada hubungan penyebab dapat dikesan bagi kes Filipina. Dua hasil penting daripada kajian ini adalah: (1) Kajian ini mencadangkan bahawa krisis kewangan Asia dan krisis ekonomi global memberikan kesan yang berbeza terhadap hubungan dinamik antara pasaran saham dengan kadar pertukaran di tiga negara yang dikaji; (2) Implikasi dasar ekonomi berkaitan hubungan antara pasaran saham dengan kadar pertukaran adalah bersifat khusus kepada sesebuah negara.
\end{abstract}

Kata Kunci: SP, REER, kointegrasi, Penyebab Granger, perubahan struktur. 


\begin{abstract}
Purpose - The main aim of this paper is to study the relationship between stock markets and exchange rates in selected ASEAN countries namely Malaysia, Thailand and the Philippines. In addition to looking at the longrun cointegration relationship between stock market and exchange rate, this study tries to examine the causality pattern of short-run relationship in the three countries.
\end{abstract}

Design/methodology/approach - The study uses monthly data covering the period from January 1994 to September 2011. Several techniques are used including $A D F, P P$, and SL unit root tests, long-run Johansen cointegration test with structural breaks, vector error correction model (VECM) and TodaYamamoto approaches for short-run Granger causality test.

Findings - The study indicates a cointegrating relationship between stock market and exchange rate for the case of Malaysia and the Philippines. The short-run Granger causality test showed two way causal relationship between stock market and exchange rate in Malaysia and Thailand, but none in the Philippines. The study suggests that the Asian financial crisis and global economic crisis give different impacts on the dynamic relationship between stock markets and exchange rates in the three countries studied. Thus, the economic policy implications of the said relationships are specific to a country.

Originality/value - This study examines the relationship between the stock market and the exchange rate, the negative impact of the economic crises (structural breaks) and related policy implications for investors and policy makers in particular and the country in general.

Keywords: SP, REER, cointegration, Granger Causality, structural breaks.

Paper type: Research Paper.

\title{
Pengenalan
}

Pasaran kewangan memainkan peranan penting sebagai saluran transmisi informasi kewangan antara satu pasaran dengan pasaran lain sama ada di sebuah negara, kawasan serantau mahupun seluruh dunia. Tambahan pula, aktiviti liberalisasi dan globalisasi kewangan dipercayai meningkatkan lagi darjah integrasi antara satu pasaran dengan pasaran lain secara meluas tanpa sempadan. Ekoran kecenderungan darjah peningkatan integrasi antara pasaran-pasaran 
kewangan sejak kebelakangan ini, keperluan untuk mengkaji dan memantau perjalanan serta gelagat pasaran ini sudah semestinya diberikan keutamaan kerana hubung kait ini boleh memberikan implikasi dasar bukan sahaja kepada para pelabur tetapi juga kepada penggubal dasar sesebuah negara. Pasaran saham dan mata wang misalnya dilihat semakin mendapat tumpuan sejak berlakunya krisis kewangan Asia pada tahun 1997 dan sekali lagi selepas krisis ekonomi global 2008 dengan kejatuhan teruk dalam pasaran saham dan mata wang yang akhirnya membawa kepada kelembapan ekonomi Asia khususnya di negara atau pasaran baru muncul (EMs) (Diamandis \& Drakos, 2011).

Menurut Solnik dan McLeavey (2009, hlm. 145), EMs berbeza dengan negara maju. Ekonomi EMs biasanya tidak pelbagai dan sangat bergantung pada pelaburan asing. Justeru, kejatuhan dalam nilai mata wang EMs selalunya memberikan tanda-tanda awal bahawa negara terbabit sedang berhadapan dengan masalah. Solnik dan McLeavey (2009, hlm. 145) menyifatkan EMs sebagai telah 'ditakdirkan' mempunyai pasaran mata wang dan saham yang sangat berkait rapat dengan keadaan ekonomi dan politik di negara terbabit. Hubung kait ini adalah positif dan sangat kuat. Oleh sebab itu, para pelabur biasanya akan menerima kesan negatif berganda akibat daripada kejatuhan mata wang EMs. Para pelabur bukan sahaja kehilangan aset yang ditukar dalam mata wang domestik, tetapi juga kerugian kerana kejatuhan nilai mata wang domestik di pasaran saham EMs.

Di samping melihat hubungan kointegrasi jangka panjang antara pasaran saham dengan pertukaran asing, kajian ini cuba mengkaji corak hubungan jangka pendek di tiga negara ASEAN iaitu Malaysia, Thailand dan Filipina dengan menggunakan data siri masa bulanan bermula Januari 1994 hingga September 2011. Untuk mencapai objektif kajian, beberapa teknik pengujian digunakan termasuklah ujian punca unit ADF, PP dan SL, ujian kointegrasi Johansen dengan perubahan struktur, Vektor Model Pembetulan Ralat (VECM) dan pendekatan Toda-Yamamoto untuk ujian penyebab Granger jangka pendek. Berbanding kebanyakan kajian lepas, kelebihan dan kekuatan kajian ini adalah mengambil kira kemungkinan kehadiran perubahan struktur yang signifikan dalam data siri masa khususnya yang disebabkan oleh krisis kewangan Asia 1997 dan krisis kewangan global 2008.

Dalam menjelaskan hubungan antara pasaran saham dengan pertukaran asing, terdapat beberapa teori yang berkaitan dan sering diguna pakai. Dua daripadanya adalah berdasarkan pendekatan 
aliran (flow) dan stok (stock). Menurut pendekatan aliran, perubahan dalam kadar pertukaran akan memberikan kesan ke atas daya saing antarabangsa dan imbangan dagangan. Kenaikan dalam kadar pertukaran melalui kejatuhan dalam nilai mata wang domestik akan menguatkan lagi daya saing firma-firma domestik disebabkan eksport menjadi lebih murah berbanding import. Sebaliknya eksport menjadi lebih mahal jika berlaku kejatuhan dalam kadar pertukaran iaitu melalui kenaikan dalam nilai mata wang domestik. Justeru, pendekatan ini mencadangkan satu bentuk hubungan positif antara kedua-dua pasaran ini di mana kadar pertukaran adalah penyebab kepada pasaran saham. Sementara pendekatan stok pula merujuk kepada kepelbagaian portfolio antarabangsa apabila kadar pertukaran dinamik berfungsi dalam mengimbangi permintaan dan penawaran terhadap aset-aset kewangan domestik dan asing. Menurut pendekatan ini, apabila harga ekuiti domestik meningkat, peningkatan ini akan menyebabkan kejatuhan dalam kadar pertukaran iaitu melalui kenaikan dalam nilai mata wang domestik. Hal ini disebabkan peningkatan permintaan terhadap wang domestik untuk membeli ekuiti domestik. Justeru, pendekatan ini mencadangkan satu bentuk hubungan negatif antara kedua-dua pasaran ini di mana pasaran saham adalah penyebab kepada pasaran kadar pertukaran (Yau \& Nieh, 2009; Zhao, 2010).

Struktur kajian ini dibahagikan kepada lima bahagian. Bahagian kedua membincangkan kajian lepas tentang pasaran saham dan kadar pertukaran. Bahagian ketiga membincangkan tentang metodologi dan data. Bahagian keempat tentang dapatan kajian dan bahagian kelima ialah kesimpulan dan menutup perbincangan.

\section{Kajian Lepas}

Sebelum berlakunya krisis kewangan Asia pada tahun 1997, terdapat sejumlah kajian yang melihat hubungan antara pasaran saham dengan kadar pertukaran sama ada secara langsung ataupun tidak langsung. Hal ini adalah kerana kedua-dua pasaran ini dipercayai mempunyai hubung kait yang rapat antara satu sama lain (antaranya Biger, 1979; Aggarwal, 1981; Solnik, 1987; Senoen \& Hennigar, 1988; Ma \& Kao, 1990; Jorion, 1990, 1991; Bailey \& Chung, 1995; Abdalla \& Murinde, 1997; Chow, Lee \& Solt, 1997).

Kewujudan krisis kewangan Asia pada pertengahan 1997 terbukti telah mengukuhkan lagi tanggapan bahawa kedua-dua pasaran saham dan kadar pertukaran saling berhubung kait. Sebagai contoh, 
melihat senario pasaran Malaysia ketika krisis kewangan Asia berlaku, nilai mata wang ringgit Malaysia telah jatuh sebanyak 37.40 peratus dalam tempoh bermula 1 Julai hingga 30 September 1997. Pada tempoh yang sama, pasaran saham Malaysia juga telah jatuh sebanyak 31.37 peratus. Situasi yang sama juga berlaku di kebanyakan pasaran kewangan Asia yang lain (Baharumshah, Masih \& Azali, 2002). Krisis ini yang juga dikenali sebagai 'demam Asia' (Granger, Huang \& Yang, 2000) telah menyebabkan kedua-dua pasaran saham dengan kadar pertukaran menjadi semakin penting untuk dikaji.

Antara isu menarik yang semakin mendapat perhatian ialah corak hubungan penyebab antara pasaran saham dengan kadar pertukaran. Misalnya, menurut Granger, Huang dan Yang (2000), kewujudan krisis kewangan Asia 1997 telah menimbulkan dilema persoalan tentang siapakah penyebab kepada kejatuhan dalam pasaran saham dan kadar pertukaran. Adakah pasaran saham penyebab kepada kejatuhan dalam pasaran kadar pertukaran atau sebaliknya? Sementara daripada perspektif keuntungan, jika hubungan dinamik antara kedua-dua pasaran ini dapat ditentukan secara statistik, dipercayai peluang untuk mendapatkan untung daripada aktiviti arbitraj boleh diperoleh terutama sekali ketika berlaku krisis kewangan yang teruk (Granger et al., 2000).

Antara kalangan penyelidik yang percaya bahawa krisis kewangan Asia 1997 cenderung mencerminkan hubung kait yang rapat antara pasaran ekuiti dan pasaran kadar pertukaran termasuklah Granger et al. (2000) dan Baharumshah et al. (2002). Tambahan lagi, krisis ekonomi juga dipercayai boleh mengubah corak hubungan antara pasaran saham dan kadar pertukaran (Pan, Fok \& Liu, 2007).

Selain itu, pengetahuan tentang hubungan penyebab dan darjah integrasi antara kedua-dua pasaran ini juga boleh memberikan maklumat yang penting kepada para pelabur antarabangsa, syarikatsyarikat multinasional dan para pembuat dasar (Ajayi, Friedman \& Mehdian, 1998). Walau bagaimanapun, Hatemi-J dan Roca (2005) dalam kajian mereka mencadangkan bahawa pelabur-pelabur di pasaran saham tidak boleh menggunakan pasaran pertukaran asing sebagai strategi lindung nilai yang berkesan untuk pelaburan mereka dan begitu juga sebaliknya para pelabur di pasaran pertukaran asing tidak boleh menggunakan pasaran saham sebagai strategi lindung nilai pelaburan mereka di sepanjang tempoh krisis. Sementara itu, para pembuat dasar yang cuba memanipulasikan kadar pertukaran untuk menaikkan pasaran saham dalam tempoh krisis juga dilihat sebagai pilihan yang kurang bijak. 
Berdasarkan sejumlah kajian lepas tentang hubungan antara pasaran saham dengan kadar pertukaran, hasil keputusan yang diperoleh adalah bercampur-campur. Kajian oleh Wu (2001) misalnya mendapati bahawa kadar pertukaran dolar Singapura berbanding mata wang negara-negara maju berhubung kait secara negatif dengan pasaran saham Singapura dalam kedua-dua tempoh sebelum dan semasa krisis kewangan Asia 1997-1998. Sementara kadar pertukaran berbanding ringgit Malaysia berhubung kait secara positif dengan pasaran saham Singapura.

Kajian di negara Pasifik Basin pula menunjukkan pasaran saham dan kadar pertukaran berhubungan secara positif di mana pasaran saham Amerika Syarikat (AS) dilihat bertindak sebagai saluran yang signifikan kepada hubung kait ini. Dengan menggunakan aplikasi penganggaran rekursif, bukti empirikal menunjukkan bahawa krisis kewangan mempunyai kesan yang sementara ke atas pergerakan bersama dalam jangka panjang bagi pasaran-pasaran ini (Phylaktis \& Ravazzolo, 2005). Kajian Ma dan Kao (1990) pula mencadangkan, bagi negara yang berorientasikan eksport, kenaikan nilai mata wang memberikan kesan negatif ke atas pasaran saham, sementara kenaikan nilai mata wang meningkatkan pasaran saham bagi negara yang berorientasikan import. Hal ini adalah kerana kenaikan nilai mata wang bukan sahaja menjadikan eksport tidak kompetitif, tetapi juga menjejaskan pengeluaran dan harga saham. Sebaliknya, kenaikan nilai mata wang akan menyebabkan kos import menjadi lebih murah yang seterusnya menggalakkan pengeluaran dan peningkatan harga saham (Sarmidi \& Mohd Nor, 2001).

Kajian di negara Asia terpilih menunjukkan bahawa kadar pertukaran adalah penyebab kepada harga saham bagi kes Korea Selatan. Sementara harga saham adalah penyebab kepada kadar pertukaran dengan korelasi negatif di Filipina (Granger et al., 2000). Sebaliknya, kajian oleh Azman-Saini, Dayang-Afizzah, Law dan Habibullah (2007a) di Filipina menunjukkan wujud hubungan penyebab dua hala antara pasaran saham dan kadar pertukaran. Bagi kes di Hong Kong, Malaysia, Singapura, Thailand dan Taiwan pula, hasil kajian menyokong kedua-dua hubungan dua hala yang kuat antara harga saham dan kadar pertukaran (Granger et al., 2000; Azman-Saini, Habibullah \& Azali, 2003a; 2003b; Azman-Saini, Habibullah, Law \& Dayang-Afizzah, 2007b). Walau bagaimanapun, hasil kajian gagal membuktikan sebarang bentuk hubungan penyebab antara harga saham dengan kadar pertukaran bagi kes Jepun dan Indonesia (Granger et al., 2000). Menurut Wu (2000), kedua-dua mata wang 
Singapura yang mengalami peningkatan berbanding dolar AS dan ringgit Malaysia; dan mengalami penurunan berbanding yen Jepun dan rupiah Indonesia telah menyebabkan peningkatan harga saham dalam kebanyakan tempoh tertentu dalam tahun-tahun 1990-an. Namun, bagi kes yang berkaitan dengan AS, kadar pertukaran dolar mempunyai tanda kebalikan antara tempoh krisis 1997-1998 dan tempoh pemulihan 1999-2000. Pengaruh kadar pertukaran ke atas harga saham pula dilihat semakin meningkat mengikut kronologi dalam tahun-tahun 1990an.

Kajian lain (Hatemi-J \& Roca, 2005) menunjukkan bahawa dalam tempoh sebelum krisis Asia, kadar pertukaran dan harga saham berhubungan secara signifikan yang kadar pertukaran adalah penyebab kepada harga saham bagi kes Indonesia dan Thailand, sementara harga saham adalah penyebab kepada kadar pertukaran bagi kes Malaysia. Sebaliknya, hasil kajian oleh Pan et al. (2007) menunjukkan wujud hubungan penyebab yang signifikan daripada kadar pertukaran kepada harga saham bagi kes Hong Kong, Jepun, Malaysia dan Thailand sebelum krisis kewangan Asia 1997. Hasil kajian ini oleh Hatemi-J dan Roca (2005) dan Pan et al. (2007) bertentangan dengan hasil kajian oleh Azman-Saini et al. (2003a; 2007b) bagi kes Malaysia dan Thailand apabila wujud hubungan penyebab dua hala antara pasaran saham dengan kadar pertukaran pada tempoh sebelum krisis. Kajian Pan et al. (2007) juga menunjukkan hubungan penyebab daripada pasaran ekuiti kepada pasaran pertukaran asing wujud bagi kes Hong Kong, Korea dan Singapura. Selain itu, wujud hubungan penyebab daripada kadar pertukaran kepada harga saham di Malaysia dan Thailand (AzmanSaini et al., 2003a; 2007b) dan di semua negara kecuali Malaysia (Pan et al., 2007) pada masa krisis Asia. Sebaliknya, tiada negara yang menunjukkan hubungan penyebab yang signifikan daripada harga saham kepada kadar pertukaran. Kajian oleh Broome dan Morley (2004) menunjukkan bahawa harga saham domestik, harga saham Hong Kong dan terutama sekali harga saham AS adalah indikator utama kepada krisis. Hasil kajian mereka juga menunjukkan wujud hubungan penyebab dua hala antara pasaran saham dengan pasaran pertukaran asing.

Tidak dinafikan bahawa kewujudan krisis kewangan Asia 1997 telah membawa kepada peningkatan secara drastik kajian ke atas pasaran saham dan kadar pertukaran. Peningkatan ketara dalam kajian berkaitan juga berlaku selepas krisis kewangan global pada tahun 2008 (Diamandis \& Drakos, 2011). Hal ini memberi gambaran 
bahawa kajian tentang hubungan antara kedua-dua pasaran ini sangat penting memandangkan kemusnahan besar yang boleh diakibatkan oleh pasaran-pasaran ini ke atas ekonomi sesebuah negara terutama apabila berlaku sesuatu krisis ekonomi atau krisis kewangan yang tidak dijangka. Kesan yang lebih teruk dapat dirasai jika kedua-dua pasaran ini saling berhubung kait kerana kombinasi secara bersama boleh memberikan impak yang sangat besar ke atas ekonomi sesebuah negara seperti Malaysia. Tambahan lagi, menurut Pan et al. (2007), krisis ekonomi seperti krisis kewangan Asia 1997 mungkin boleh mengubah hubungan semula jadi dan corak pergerakan bersama antara harga saham dengan kadar pertukaran. Hal ini kerana bermula awal Julai 1997 sehingga satu atau dua tahun berikutnya, beberapa negara Asia Timur telah mengalami kejatuhan yang besar dalam mata wang mereka sebagaimana kejatuhan yang teruk dalam pasaran saham. Kejatuhan nilai mata wang dan harga saham semasa krisis telah membuktikan bahawa kadar pertukaran dan harga saham cenderung untuk bergerak bersama walaupun hubungan penyebab tidak jelas sama ada daripada kadar pertukaran kepada harga saham atau sebaliknya.

\section{Metodologi dan Data}

Tidak seperti kebanyakan kajian lepas, kajian ini turut mengambil kira kesan kewujudan perubahan struktur dalam analisis kepegunan dan kointegrasi. Ujian punca unit secara konvensional seperti ADF dan PP dikritik kerana kegagalan dalam mengambil kira perubahan struktur. Menurut Perron (1989), kegagalan dalam mengambil kira kesan perubahan struktur dalam ujian punca unit akan menyebabkan hasil keputusan yang bias iaitu mengurangkan keupayaan dalam menolak hipotesis nol punca unit yang salah (lihat juga Glynn, Perera \& Verma, 2007; Byrne \& Perman, 2007). Umumnya, terdapat dua kelebihan prosedur pengujian punca unit dengan mengambil kira perubahan struktur; (1) mencegah daripada mendapat hasil keputusan ujian yang bias; dan (2) dapat memberikan maklumat penting dalam analisis sama ada perubahan struktur yang berlaku dalam pemboleh ubah tertentu adalah berkaitan dengan antara lain, pelaksanaan dasar ekonomi oleh kerajaan, krisis ekonomi, peperangan, peralihan rejim dan sebagainya (Glynn et al., 2007). Walau bagaimanapun, pembangunan pengujian punca unit dengan perubahan struktur telah menimbulkan persoalan bagaimana perubahan struktur ini boleh diambil kira dalam memodelkan hubungan kointegrasi antara pemboleh ubah dalam kajian. Justeru, persoalan ini telah membawa kepada pembentukkan kaedah kointegrasi dengan mengambil 
kira perubahan struktur. Antaranya, Gregory dan Hansen (1996), Saikkonen dan Lutkepohl (2000) dan juga Johansen, Mosconi dan Nielsen (2000). Namun analisis kointegrasi dalam kajian ini mengguna pakai pendekatan Johansen et al. (2000).

Untuk menentukan kepegunan dan peringkat integrasi data siri pemboleh ubah, kajian ini menggunakan ujian-ujian punca unit berdasarkan Dickey-Fuller tambahan, ADF (Dickey \& Fuller, 1979; 1981), Phillips-Perron, PP (Phillips \& Perron, 1988) dan ujian punca unit dengan perubahan struktur oleh Saikkonen-Lutkepohl, SL (Saikkonen \& Lutkepohl, 2002; Lanne, Lutkepohl \& Saikkonen, 2002; 2003).

Ujian punca unit SL ke atas data siri masa $y_{t}$ dapat ditunjukkan seperti berikut:

$$
y_{t}=\mu_{0}+f_{t}(\theta)^{\prime} \gamma+x_{t}
$$

Ralat $x_{t}$ diperoleh melalui proses $A R(p)$ yang mewakili $\alpha(L)(1-\rho L) x_{t}=u_{t}$ di mana $\alpha(L)=1-\alpha_{1} L^{-} \ldots-\alpha_{\mathrm{p}-1} L^{\mathrm{p}-1}$ dan $u_{\mathrm{t}} \operatorname{iid}\left(0, \sigma^{2}\right)$. Parameter $\rho$ adalah $-1<\rho \leq 1$ dan $\rho=1$ menunjukkan proses punca unit. Dalam bentuk pembezaan pertama, persamaan (1) boleh ditulis sebagai

$$
\Delta y_{t}=\Delta f_{t}(\theta)^{\prime} \gamma+v_{t}
$$

di mana $v_{t}=\alpha(L)^{-1} u_{t}$. Sementara fungsi peralihan di mana tarikh peralihan, $T_{E}$ diwakili oleh dami peralihan, $d_{t}$ ditakrifkan seperti berikut:

$$
f_{t}(\theta)^{\prime} \equiv d_{t}= \begin{cases}0 & t<T_{B} \\ 1 & t \geq T_{B}\end{cases}
$$

Panjang lat yang optimum dipilih berdasarkan kriteria maklumat Schwarz (SIC). Sementara taburan nilai kritikal bagi ujian ini adalah berdasarkan Lanne et al. (2002).

Sementara analisis kointegrasi dalam kajian ini pula adalah berdasarkan prosedur ujian trace kointegrasi Johansen dengan mengambil kira perubahan struktur (Johansen et al., 2000). Prosedur pengujian kointegrasi dalam kes ini hampir sama dengan prosedur pengujian kointegrasi oleh Saikkonen dan Lutkepohl (lihat Saikkonen \& Lutkepohl, 2000; Trenkler, 2002; Lutkepohl, Saikkonen \& Trenkler, 2003; Lutkepohl, 2004). Proses penjanaan data (DGP) bagi $Y_{t}$ secara ringkasnya dapat ditunjukkan seperti berikut: 


$$
y_{t}=\mu_{0}+\delta d_{t}+x_{t}
$$

di mana dami peralihan, $d_{t}$ mempunyai takrifan yang sama seperti dalam ujian punca unit berdasarkan SL dalam persamaan (3). Oleh itu, tarikh perubahan struktur adalah berdasarkan tarikh yang dipilih dalam ujian SL. Pendekatan kointegrasi Johansen dengan perubahan struktur ini juga boleh ditulis dalam bentuk VECM seperti berikut:

$$
\Delta y_{t}=v+\Pi\left[\begin{array}{l}
y_{t-1} \\
d_{t-1}
\end{array}\right]+\sum_{j=1}^{p-1} \Gamma_{\mathrm{j}} \Delta \mathrm{y}_{\mathrm{t}-\mathrm{j}}+\sum_{j=0}^{p-1} \Delta d_{t-j}+u_{t}
$$

di mana $v=-\Pi \mu_{0}$ dan $\Pi=\alpha\left[\beta^{\prime}: \theta\right] \operatorname{dan} \theta=-\beta^{\prime} \delta$.

Selain itu, ujian penyebab Granger dan analisis hubungan jangka pendek dalam kajian ini adalah berdasarkan kepada rangka kerja vektor autoregresi (VAR). Bagi kes di mana $y_{t}$ dan $x_{t}$ adalah pemboleh ubah pegun $I(0)$, persamaan (6) dan (7) tanpa pemboleh ubah pembetulan ralat boleh dianggarkan dengan menggunakan kaedah kuasa dua terkecil (OLS) dalam bentuk peringkat aras. Bagaimanapun, jika $y_{t}$ dan $x_{t}$ adalah pemboleh ubah yang tidak pegun, I(1) dan tidak berkointegrasi, model VAR seperti persamaan (6) dan (7) tanpa pemboleh ubah pembetulan ralat dalam bentuk peringkat pembezaan pertama boleh digunakan. Sementara persamaan (6) dan (7) berdasarkan rangka kerja VECM untuk analisis jangka pendek dan jangka panjang boleh digunakan bagi kes di mana $y_{t}$ dan $x_{t}$ adalah $I(1)$ dan berkointegrasi.

$$
\begin{aligned}
& \Delta y_{t}=\alpha_{0}+\sum_{i=1}^{n} \alpha_{1 i} \Delta y_{t-i}+\sum_{i=1}^{n} \alpha_{2 i} \Delta x_{t-i}+\alpha_{3} E C_{t-1}+\varepsilon_{y t} \\
& \Delta x_{t}=\beta_{0}+\sum_{i=1}^{n} \beta_{1 i} \Delta y_{t-i}+\sum_{i=1}^{n} \beta_{2 i} \Delta x_{t-i}+\beta_{3} E C_{t-1}+\varepsilon_{x t}
\end{aligned}
$$

di mana $E C_{\mathrm{t}-1}$ ialah pemboleh ubah pembetulan ralat atau vektor kointegrasi yang diperoleh daripada ujian kointegrasi. $x_{t}$ ialah penyebab Granger kepada $y_{t}$ jika semua $a_{2 \mathrm{i}}$ dalam persamaan (6) adalah signifikan tanpa mengambil kira $\beta_{1 \mathrm{i}}$ dalam persamaan (7). Sebaliknya adalah penyebab Granger kepada jika semua dalam persamaan (7) adalah signifikan tanpa mengambil kira $a_{2 \mathrm{i}}$ dalam persamaan (6). Sementara hubungan penyebab dua hala wujud antara $x_{t}$ dan $y_{t}$ jika semua $a_{2 \mathrm{i}}$ dan $\beta_{1 \mathrm{i}}$ adalah signifikan. Parameter $a_{3}$ dan $\beta_{3}$ adalah merujuk kepada koefisien pembetulan ralat atau kelajuan pelarasan dan juga koefisien penyebab jangka panjang.

Ujian penyebab Granger yang telah diubah suai dan dianggap lebih berkuasa tinggi telah dibangunkan oleh Toda dan Yamamoto (1995) untuk mengatasi masalah berhubung dengan taburan nilai kritikal 
asimptotik yang tidak sah apabila ujian penyebab dijalankan ke atas data siri masa yang tidak pegun. Menurut Toda dan Yamamoto (TY), pendekatan TY pada dasarnya melibatkan penganggaran ke atas model VAR $\left(k+d_{\max }\right)$ di mana $k$ adalah panjang lat yang optimum dalam sistem VAR yang asal dan $d_{\max }$ adalah peringkat integrasi yang maksimum bagi pemboleh ubah dalam sistem VAR. Pendekatan TY menggunakan statistik ujian Wald diubah suai (MWald) untuk kekangan sifar ke atas parameter dalam model VAR (k). Baki parameter autoregresif dengan lat, $d_{\max }$ diandaikan sifar dan dibiarkan dalam model VAR $\left(k+d_{\max }\right)$. Ujian ini mempunyai taburan khi-kuasa dua asimptotik dengan $k$ darjah kebebasan yang terhad apabila model VAR $\left(k+d_{\max }\right)$ dianggarkan. Pendekatan TY dalam bentuk bivariat boleh ditulis seperti berikut:

$$
\begin{aligned}
& y_{t}=\alpha_{0}+\sum_{i=1}^{k+d_{\max }} \alpha_{1 i} y_{t-i}+\sum_{i=1}^{k+d_{\max }} \alpha_{2 i} x_{t-i}+u_{t} \\
& x_{t}=\beta_{0}+\sum_{i=1}^{k+d_{\max }} \beta_{1 i} y_{t-i}+\sum_{i=1}^{k+d_{\max }} \beta_{2 i} x_{t-i}+v_{t}
\end{aligned}
$$

di mana $a$ dan $\beta$ adalah parameter tidak diketahui, $k$ adalah panjang lat optimum dan $d_{\max }$ adalah peringkat integrasi yang maksimum bagi pemboleh ubah dalam sistem. Selain itu, $u$ dan $v$ adalah ralat rawak dan diandaikan sebagai gangguan putih (white noise). Panjang lat, $k$ pada awalnya dipilih berdasarkan SIC. Bagaimanapun, panjang lat, $k$ kemudiannya ditambah dengan lebih banyak lat bergantung kepada peringkat integrasi yang mungkin, $d_{\max }$ bagi siri pemboleh ubah $y_{t}$ dan $x_{t}$ Ujian kesignifikanan dilakukan ke atas pemboleh ubah dalam sistem VAR hanya sehingga lat $k$ tidak termasuk tambahan lat, $d_{\max }$ dalam menentukan hubungan penyebab antara $y_{t}$ dan $x_{t}$ dalam sistem VAR.

Untuk tujuan analisis, kajian ini menggunakan data bulanan bermula Januari 1994 hingga September 2011. Indeks harga saham (SP) sebagai proksi kepada pasaran saham dan kadar pertukaran efektif benar (REER) sebagai proksi kepada kadar pertukaran bagi setiap negara iaitu (MSP, MREER) Malaysia, (TSP, TREER) Thailand dan (FSP, FREER) Filipina diperoleh daripada Thomson datastream. Kedua-dua SP dan REER adalah dalam bentuk logaritma.

\section{Dapatan Kajian}

Rajah 1 menunjukkan corak trend indeks harga saham dan kadar pertukaran efektif benar di Malaysia (MSP, MREER), Thailand (TSP, TREER) dan Filipina (FSP, FREER) bagi tempoh Januari 1994 hingga 
September 2011. Secara umum berlaku turun naik yang agak ketara dalam kedua-dua siri pemboleh ubah di semua negara terlibat. Krisis kewangan Asia 1997-1998 juga memberikan kesan yang agak signifikan ke atas kedua-dua siri pemboleh ubah khususnya di Malaysia dan Thailand tetapi kurang signifikan bagi kes Filipina. Sementara krisis kewangan global 2008 tidak begitu memberikan kesan yang signifikan ke atas REER tetapi memberikan kesan ke atas SP di semua negara terlibat. Jika dibandingkan dengan Malaysia dan Thailand, terdapat perbezaan trend dalam kedua-dua SP dan REER yang agak ketara dalam kes Filipina. Ringkasnya, rajah tersebut memberikan gambaran umum bahawa kemungkinan berlaku perubahan struktur dalam kedua-dua data siri masa di semua negara terlibat dalam tempoh masa kajian.

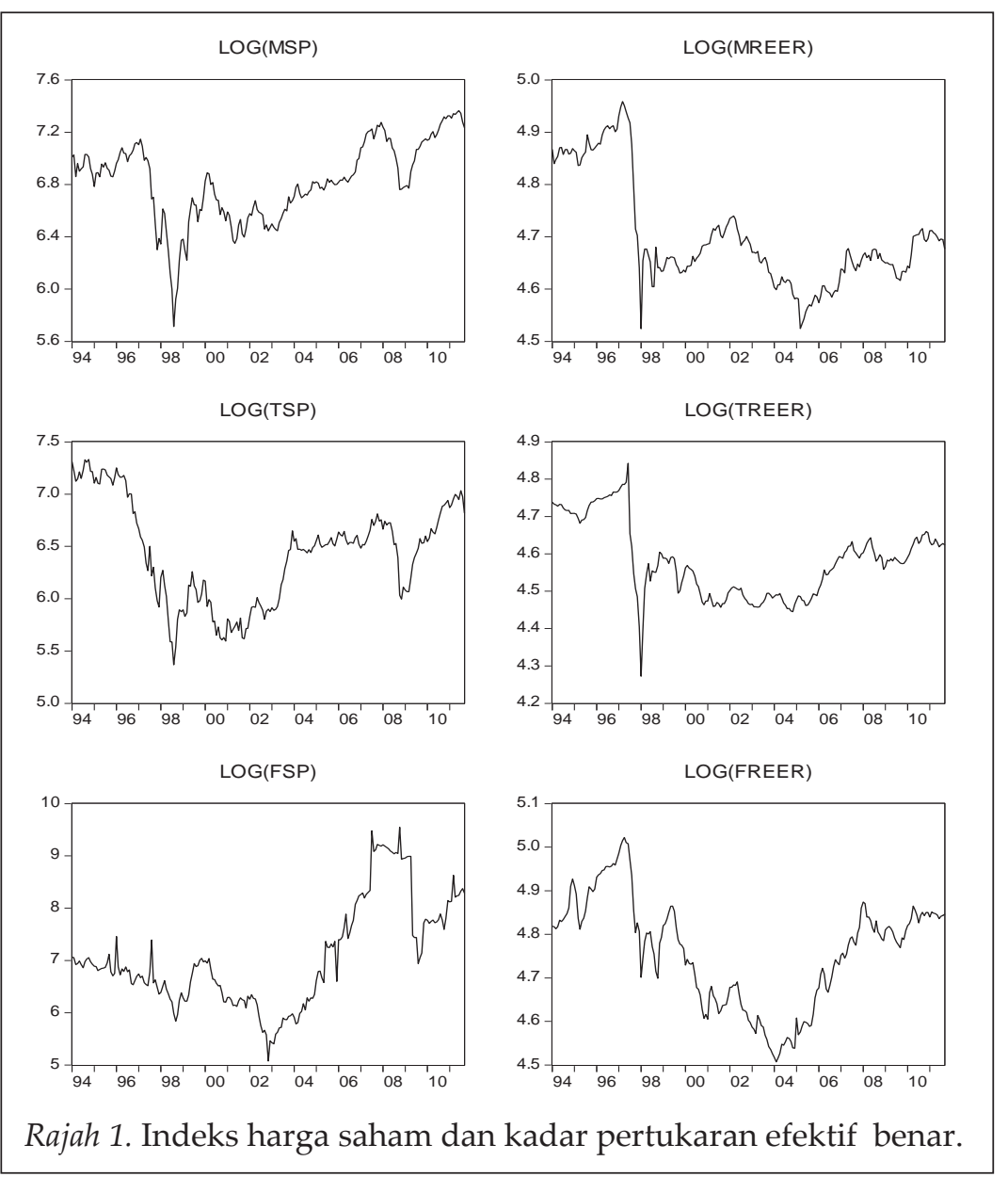


Hasil ujian punca unit berdasarkan ADF dan PP menunjukkan kesemua siri pemboleh ubah tidak pegun pada peringkat aras, $I(0)$ tetapi pegun pada peringkat pembezaan pertama, I(1). Keputusan ini adalah konsisten bagi Malaysia, Thailand dan Filipina (lihat Jadual 1 dan Jadual 2). Sementara ujian punca unit berdasarkan SL (Jadual 3) dengan perubahan struktur menunjukkan hipotesis nol proses punca unit dengan perubahan struktur tidak dapat ditolak dalam semua kes kecuali REER dalam kes Thailand. Hal ini memberi gambaran bahawa krisis kewangan Asia 1997 mungkin memberikan kesan yang signifikan ke atas kadar pertukaran Thailand. Hasil keputusan ujian SL juga menunjukkan bahawa Februari 1998 dan Ogos 1998 masingmasing merupakan tarikh perubahan struktur bagi REER dan SP dalam kes Malaysia. Sementara Julai 1997 dan Oktober 2008 masingmasing merupakan tarikh perubahan struktur bagi REER dan SP dalam kes Thailand dan Januari 1998 dan Mei 2009 masing-masing merupakan tarikh perubahan struktur bagi REER dan SP dalam kes Filipina.

Jadual 1

Ujian Punca Unit Dickey-Fuller Tambahan

\begin{tabular}{cccccc}
\hline Negara & $\begin{array}{c}\text { Pemboleh } \\
\text { ubah }\end{array}$ & \multicolumn{2}{c}{ Aras } & \multicolumn{2}{c}{ Beza Pertama } \\
\cline { 3 - 6 } & & Pemalar & $\begin{array}{c}\text { Pemalar \& } \\
\text { Trend }\end{array}$ & Pemalar & $\begin{array}{c}\text { Pemalar \& } \\
\text { Trend }\end{array}$ \\
\hline \multirow{2}{*}{ Malaysia } & SP & $-1.9189(1)$ & $-2.5030(1)$ & $-12.3653^{* *}(0)$ & $-12.3866^{* *}(0)$ \\
& REER & $-1.8699(0)$ & $-1.7097(0)$ & $-13.1054^{* *}(0)$ & $-13.0977^{* *}(0)$ \\
\multirow{3}{*}{ Thailand } & SP & $-1.8739(0)$ & $-1.8091(0)$ & $-13.7460^{* *}(0)$ & $-13.8561^{* *}(0)$ \\
& REER & $-2.4733(1)$ & $-2.3385(1)$ & $-11.8582^{*}(0)$ & $-11.8725^{* *}(0)$ \\
\multirow{2}{*}{ Filipina } & SP & $-1.1625(1)$ & $-1.9462(1)$ & $-17.5196^{* *}(0)$ & $-17.5178^{* *}(0)$ \\
& REER & $-1.5635(1)$ & $-1.4442(1)$ & $-11.2558^{* *}(0)$ & $-11.2575^{* *}(0)$ \\
\hline
\end{tabular}

Nota.

** dan * adalah signifikan pada 1\% dan 5\%. Angka dalam ( ) adalah panjang lat yang dipilih berdasarkan Kriteria Maklumat Schwarz (SIC).

Dengan mengambil kira kehadiran perubahan struktur dalam data siri masa yang mungkin mempengaruhi hubungan antara pasaran saham dengan kadar pertukaran, analisis kointegrasi diteruskan dengan menggunakan ujian kointegrasi Johansen yang mengambil kira perubahan struktur. Hasil keputusan ujian ditunjukkan dalam Jadual 4. Dalam analisis ini, tarikh perubahan struktur dalam memodelkan hubungan antara pasaran saham dengan kadar 
pertukaran bagi setiap negara dipilih berdasarkan ujian SL ke atas reja yang diperoleh dengan menggunakan kaedah kuasa dua terkecil (OLS) ke atas persamaan $\mathrm{SP}=f($ REER). Ujian kointegrasi Johansen dengan perubahan struktur membenarkan sehingga dua tarikh perubahan struktur dalam menganalisis hubungan jangka panjang (kointegrasi) antara pemboleh ubah dalam kajian. Hasil ujian menunjukkan bahawa wujud hubungan kointegrasi (dengan kemungkinan perubahan struktur) antara SP dan REER dalam kes Malaysia dan Filipina tetapi tiada kointegrasi dapat dikesan dalam kes Thailand.

Jadual 2

Ujian Punca Unit Phillips-Perron

\begin{tabular}{cccccc}
\hline \multirow{2}{*}{ Negara } & $\begin{array}{c}\text { Pemboleh } \\
\text { Ubah }\end{array}$ & Pemalar & $\begin{array}{c}\text { Pemalar \& } \\
\text { Trend }\end{array}$ & Pemalar & $\begin{array}{c}\text { Pemalar \& } \\
\text { Trend }\end{array}$ \\
\hline \multirow{2}{*}{ Malaysia } & SP & $-1.8861(3)$ & $-2.4351(3)$ & $-12.3086^{* *}(7)$ & $-12.3131^{* *}(8)$ \\
& REER & $-1.9874(5)$ & $-1.9741(6)$ & $-13.1375^{* *}(5)$ & $-13.1248^{* *}(5)$ \\
Thailand & SP & $-1.9496(3)$ & $-1.8285(1)$ & $-13.7433^{* *}(1)$ & $-13.8545^{* *}(1)$ \\
& REER & $-2.2764(1)$ & $-1.9166(0)$ & $-11.8183^{* *}(6)$ & $-11.8196^{* *}(6)$ \\
\multirow{2}{*}{ Filipina } & SP & $-1.3397(1)$ & $-2.0543(2)$ & $-17.5405^{* *}(1)$ & $-17.5178^{* *}(0)$ \\
& REER & $-1.4403(3)$ & $-1.3014(3)$ & $-11.2556^{* *}(0)$ & $-11.2575^{* *}(0)$ \\
\hline
\end{tabular}

Nota.

** adalah signifikan pada 1\%. Angka dalam ( ) adalah bandwidth berdasarkan NeweyWest menggunakan Bartlett Kernel.

Jadual 3

Ujian Punca Unit Saikkonen-Lutkepohl

\begin{tabular}{ccll}
\hline Negara & Pemboleh Ubah & \multicolumn{1}{c}{ Pemalar } & \multicolumn{1}{c}{ Pemalar \& Trend } \\
\hline \multirow{2}{*}{ Malaysia } & SP & $-1.7332(1)[8 / 1998]$ & $-2.5591(1)[8 / 1998]$ \\
& REER & $-1.5595(0)[2 / 1998]$ & $-1.0877(0)[2 / 1998]$ \\
\multirow{2}{*}{ Thailand } & SP & $-1.3008(0)[10 / 2008]$ & $-1.1483(0)[10 / 2008]$ \\
& REER & $-3.4377^{*}(1)[7 / 1997]$ & $-3.8466^{* *}(1)[7 / 1997]$ \\
\multirow{2}{*}{ Filipina } & SP & $0.1258(1)[5 / 2009]$ & $-1.2821(1)[5 / 2009]$ \\
& REER & $-1.8498(1)[1 / 1998]$ & $-1.8567(1)[1 / 1998]$ \\
\hline
\end{tabular}

Nota.

** dan * adalah signifikan pada 1\% dan 5\%. Angka dalam ( ) dan [ ] adalah panjang lat berdasarkan Kriteria Maklumat Schwarz (SIC) dan tarik perubahan struktur. 
Jadual 4

Ujian Kointegrasi Johansen dengan Perubahan Struktur

\begin{tabular}{|c|c|c|c|c|c|}
\hline Negara & $Y=f(X)$ & $T_{\mathrm{B}}$ & $\mathrm{H}_{0}: \mathrm{r}=\mathrm{r}_{0}$ & Statistik Trace & Lat \\
\hline Malaysia & $\mathrm{SP}=\mathrm{f}(\mathrm{REER})$ & 8/1997; 8/1998 & $\begin{array}{l}\mathrm{r}=0 \\
\mathrm{r} \leq 1\end{array}$ & $\begin{array}{l}61.25^{* *} \\
12.37\end{array}$ & 1 \\
\hline Thailand & $\mathrm{SP}=\mathrm{f}(\mathrm{REER})$ & 7/1997 & $\begin{array}{l}r=0 \\
r \leq 1\end{array}$ & $\begin{array}{r}14.27 \\
3.37\end{array}$ & 2 \\
\hline \multirow{2}{*}{ Filipina } & $\mathrm{SP}=\mathrm{f}(\mathrm{REER})$ & 8/1997; 6/2005 & $\begin{array}{l}r=0 \\
r \leq 1\end{array}$ & $\begin{array}{l}33.29^{*} \\
12.79\end{array}$ & 1 \\
\hline & $\mathrm{SP}=\mathrm{f}(\mathrm{REER})$ & 8/1997; 5/2009 & $\begin{array}{l}r=0 \\
r \leq 1\end{array}$ & $\begin{array}{r}14.39 \\
3.29\end{array}$ & 2 \\
\hline
\end{tabular}

Nota.

** dan * adalah signifikan pada $1 \%$ dan $5 \% . \mathrm{T}_{\mathrm{B}}=$ tarikh perubahan struktur.

Bagi kes Thailand dan Filipina tanpa hubungan kointegrasi (lihat Jadual 4), analisis hubungan dinamik antara pasaran saham dengan kadar pertukaran diteruskan dengan menggunakan pendekatan VAR (Jadual 5).

Jadual 5

Vektor Autoregresif (VAR)

\begin{tabular}{|c|c|c|c|}
\hline Negara & Hipotesis Nol, $\mathrm{H}_{0}$ & $\operatorname{VAR}(k)$ & $\chi^{2}$ \\
\hline Thailand & $\begin{array}{l}\Delta \mathrm{REER}=/>\Delta \mathrm{SP} \\
\Delta \mathrm{SP}=/>\Delta \mathrm{REER}\end{array}$ & 8 & $\begin{array}{l}26.8122^{* *} \\
41.6478^{* *}\end{array}$ \\
\hline Filipina & $\begin{array}{l}\triangle \mathrm{REER}=/>\Delta S P \\
\Delta S P=>\Delta \text { REER }\end{array}$ & 1 & $\begin{array}{l}1.7760 \\
1.1401\end{array}$ \\
\hline
\end{tabular}

Nota.

** adalah signifikan pada 1\%. =/> menunjukkan 'bukan penyebab Granger'.

Sementara VECM digunakan untuk analisis hubungan jangka pendek dan jangka panjang bagi kes Malaysia dan Filipina (wujud kointegrasi) seperti dalam Jadual 6. Hasil keputusan ujian menunjukkan bahawa hubungan penyebab Granger jangka pendek dua hala antara SP dengan REER wujud dalam kes Thailand tetapi tiada hubungan penyebab Granger dapat dikesan antara SP dengan REER di Filipina dalam kedua-dua kes berkointegrasi dan tidak berkointegrasi (lihat Jadual 4, Jadual 5 dan Jadual 6). 
Sementara hubungan penyebab jangka pendek dua hala antara SP dengan REER juga dapat dikesan dalam kes Malaysia (Jadual 6). Pada masa yang sama, hubungan penyebab jangka panjang daripada REER kepada SP juga wujud dalam kes Malaysia. Sekali gus menunjukkan hubungan penyebab Granger yang kuat daripada REER kepada SP di Malaysia. Sementara ketidakseimbangan antara REER dengan SP dalam jangka panjang diperbetulkan pada kadar yang sangat perlahan iaitu 3.3\% setiap bulan (ditunjukkan oleh nilai EC yang signifikan dalam Jadual 6). Hasil keputusan ujian dinamik penyebab Granger jangka pendek antara SP dan REER berdasarkan VAR dan VECM juga disokong dan konsisten dengan hasil keputusan ujian penyebab Granger berdasarkan pendekatan Toda-Yamamoto (Jadual 7).

Jadual 6

Vektor Model Pembetulan Ralat (VECM)

\begin{tabular}{ccccc}
\hline Negara & Hipotesis $\mathrm{Nol}, \mathrm{H}_{0}$ & $\operatorname{VAR}(k)$ & $\chi^{2}$ & EC \\
\hline \multirow{2}{*}{ Malaysia } & $\Delta \mathrm{REER}=/>\Delta \mathrm{SP}$ & \multirow{2}{*}{7} & $35.3980^{* *}$ & $-0.0334^{*}$ \\
& $\Delta \mathrm{SP}=/>\Delta$ REER & & $35.8064^{* *}$ & -0.0038 \\
\multirow{2}{*}{ Filipina } & $\Delta \mathrm{REER}=/>\Delta \mathrm{SP}$ & \multirow{2}{*}{1} & 1.7768 & 0.0013 \\
& $\Delta \mathrm{SP}=/>\Delta$ REER & & 0.6619 & 0.0020 \\
\hline
\end{tabular}

Nota.

** dan * adalah signifikan pada $1 \%$ dan $5 \%$. =/> menunjukkan 'bukan penyebab Granger'. EC = koefisien pembetulan ralat.

Jadual 7

Ujian Penyebab Toda-Yamamoto

\begin{tabular}{|c|c|c|c|c|}
\hline Negara & Hipotesis, $\mathrm{H}_{0}$ & $\operatorname{VAR}(k)$ & $k+d_{\max }$ & $\chi^{2}$ \\
\hline Malaysia & $\begin{array}{l}\text { REER }=/>\text { SP } \\
S P=/>\text { REER }\end{array}$ & 9 & 10 & $\begin{array}{l}33.8872^{* *} \\
31.6607^{* *}\end{array}$ \\
\hline Thailand & $\begin{array}{l}\text { REER }=/>\text { SP } \\
S P=/>\text { REER }\end{array}$ & 12 & 13 & $\begin{array}{l}33.9176^{* *} \\
45.1104^{* *}\end{array}$ \\
\hline Filipina & $\begin{array}{l}\text { REER }=>>\text { SP } \\
S P=>\text { REER }\end{array}$ & 2 & 3 & $\begin{array}{l}2.2596 \\
2.7348\end{array}$ \\
\hline
\end{tabular}

Nota.

** adalah signifikan pada 1\%. => menunjukkan 'bukan penyebab Granger'. 
Selain itu, beberapa siri ujian diagnostik telah dijalankan untuk memastikan model sesuai dan mencukupi di samping untuk 'memutihkan' ralat. Walau bagaimanapun, sebagaimana sifat kebiasaan dalam kebanyakan data siri masa kewangan berfrekuensi tinggi, hasil ujian diagnostik menunjukkan bahawa dalam kebanyakan ujian, andaian-andaian normal, homokedastisiti dan tiada korelasi bersiri tidak dipenuhi.

\section{Kesimpulan}

Berdasarkan sejumlah kajian lepas, pasaran saham dan pertukaran asing dilihat mempunyai darjah integrasi dan korelasi yang kuat dan signifikan khususnya di pasaran-pasaran baru muncul (EMs). Pandangan ini disokong oleh antara lain Granger et al. (2000), Baharumshah et al. (2002), Solnik dan McLeavey (2009) dan Diamandis dan Drakos (2011). Selain itu, darjah korelasi hubungan antara kedua-dua pasaran ini juga dilihat semakin meningkat pada tempoh ketika berlaku krisis kewangan khususnya krisis kewangan Asia 1997 dan global 2008 bukan sahaja di negara maju tetapi juga di negara baru muncul.

Sebagaimana dalam kajian kami, hasil ujian dengan mengambil kira perubahan struktur menunjukkan wujud hubungan kointegrasi antara pasaran saham dan kadar pertukaran bagi kes Malaysia dan Filipina. Sementara hasil ujian penyebab Granger jangka pendek berdasarkan pendekatan dinamik VECM dan Toda-Yamamoto menunjukkan wujud hubungan penyebab Granger dua hala antara pasaran saham dengan kadar pertukaran hanya dalam kes Malaysia dan Thailand dan sekali gus menyokong hasil kajian terdahulu oleh Azman-Saini et al. (2003a; 2003b; 2007b). Walau bagaimanapun, kajian di Filipina menghasilkan dapatan yang berbeza di mana kajian oleh Azman-Saini et al. (2007a) mendapati wujud hubungan penyebab dua hala antara pasaran saham dengan kadar pertukaran yang mana bercanggah dengan hasil dapatan dalam kajian kami iaitu tiada hubungan penyebab dapat dikesan bagi kes Filipina. Justeru, kajian kami mencadangkan bahawa krisis kewangan Asia dan krisis ekonomi global mungkin memberikan kesan yang berbeza terhadap hubungan dinamik antara pasaran saham dengan kadar pertukaran di tiga negara yang dikaji. Tambahan lagi, implikasi dasar ekonomi berkaitan hubungan antara pasaran saham dan kadar pertukaran adalah bersifat khusus kepada sesebuah negara. 
Walaupun kebanyakan kajian lepas sebagaimana dalam kajian ini memodelkan hubungan antara pasaran saham dengan kadar pertukaran secara langsung dalam bentuk bivariat, kajian-kajian berkaitan pada masa akan datang mungkin perlu mengambil kira saranan daripada kajian lepas iaitu pemboleh ubah lain selain harga saham dan kadar pertukaran boleh dipertimbangkan dalam memodelkan hubungan antara kedua-dua pasaran ini dalam bentuk multivariat kerana dipercayai boleh memberikan hasil keputusan yang lebih baik memandangkan terdapat pemboleh ubah lain yang mungkin mempengaruhi pasaran saham dan kadar pertukaran. Selain itu, kajian yang mengambil kira sifat asimetrik dan tak linear juga boleh dipertimbangkan dalam memodelkan hubungan antara pasaran saham dengan kadar pertukaran.

\section{Rujukan}

Abdalla, I. S. A., \& Murinde, V. (1997). Exchange rate and stock prices interactions in emerging financial markets: Evidence on India, Korea, Pakistan and the Philippines. Applied Financial Economics, 7, 25-35.

Aggarwal, R. (1981). Exchange rates and stock prices. A study of U.S. capital markets under floating exchange rates. Akron Business and Economic Review, 12(2), 7-12.

Ajayi, R. A., Friedman, J., \& Mehdian, S. M. (1998). On the relationship between stock returns and exchange rates: Tests of Granger causality. Global Finance Journal, 9(2), 241-251.

Azman-Saini, W. N. W., Dayang-Afizzah, A. M., Law, S. H., \& Habibullah, M. S. (2007a). Stock prices and exchange rates interaction: The case of the Philippines. ICFAI Journal of Applied Economics, 6(3), 7-16.

Azman-Saini, W. N. W., Habibullah, M. S., \& Azali, M. (2003a). Stock prices and exchange rates dynamics: The case of the Thailand. Savings and Development, 3, 245-258.

Azman-Saini, W. N. W., Habibullah, M. S., \& Azali, M. (2003b). Stock price and exchange rate interactions in an emerging market. RISEC: International Review of Economics and Business, 50(3), 311-324.

Azman-Saini, W. N. W., Habibullah, M. S., Law, S. H., \& DayangAfizzah, A. M. (2007b). Stock prices, exchange rates and causality in Malaysia: A note. ICFAI Journal of Financial Economics, 5(1), 7-13. 
Baharumshah, A. Z., Masih, A. M. M., \& Azali, M. (2002). The stock market and the ringgit exchange rate: $\mathrm{A}$ note. Japan and the World Economy, 14, 471-486.

Bailey, W., \& Chung, Y. P. (1995). Exchange rate fluctuations, political risk, and stock returns: Some evidence from an emerging market. Journal of Financial and Quantitative Analysis, 30(4), 541-561.

Biger, N. (1979). Exchange rate implications of international portfolio diversification. Journal of International Business Studies, 10(2), $64-74$.

Broome, S., \& Morley, B. (2004). Stock prices as a leading indicator of the East Asian financial crisis. Journal of Asian Economics, 15, $16-37$.

Byrne, J. P., \& Perman, R. (2007). Unit roots and structural breaks: A survey of the literature. In B. B. Rao (Ed.), Cointegration for the Applied Economist. Basingstoke: Palgrave Macmillan.

Chow, E. H., Lee, W. Y., \& Solt, M. E. (1997). The exchange-rate risk exposure of asset returns. Journal of Business, 70(1), 105-123.

Diamandis, P. F., \& Drakos, A. A. (2011). Financial liberalization, exchange rates and stock prices: Exogenous shocks in four Latin America countries. Journal of Policy Modeling, 33, 381-394.

Dickey, D. A., \& Fuller, W. A. (1979). Distribution of the estimation for autoregressive time series with a unit root. Journal of the American Association, 74, 427-431.

Dickey, D. A., \& Fuller, W. A. (1981). Likelihood ratio statistics for autoregressive time series with a unit root. Econometrica, 49, 1057-1072.

Glynn, J., Perera, N., \& Verma, R. (2007). Unit root tests and structural breaks: A survey with application. Revista de Metodos Cuantitativos para la Economia y la Empresa = Journal of Quantitative Methods for Economics and Business Administration, 3(1), 63-79.

Granger, C. W. J., Huang, B.-N., \& Yang, C.-W. (2000). A bivariate causality between stock prices and exchange rates: Evidence from recent Asian flu. The Quarterly Review of Economics and Finance, 40, 337-354.

Gregory. A. W., \& Hansen, B. E. (1996). Residual-based tests for cointegration in models with regime shifts. Journal of Econometrics, 70, 99-126.

Hatemi-J., \& Roca, E. (2005). Exchange rates and stock prices interaction during good and bad times. Evidence from the ASEAN4 countries. Applied Financial Economics, 15(8), 539-546. 
Johansen, S., Mosconi, R., \& Nielsen, B. (2000). Cointegration analysis in the presence of structural breaks in the deterministic trend. Econometrics Journal, 3, 216-249.

Jorion, P. (1990). The rxchange-rate exposure of U.S. multinationals. Journal of Business, 63(3), 331-345.

Jorion, P. (1991). The pricing of exchange rate risk in the stock market. Journal of Financial and Quantitative Analysis, 26(3), 363-376.

Lanne, M., Lutkepohl, H., \& Saikkonen, P. (2002). Comparison of unit root tests for time series with level shifts. Journal of Time Series Analysis, 23(6), 667-685.

Lanne, M., Lutkepohl, H., \& Saikkonen, P. (2003). Test procedures for unit roots in time series with level shifts at unknown time. Oxford Bulletin of Economics and Statistics, 65(1), 91-115.

Lutkepohl, H. (2004). Univariate time series analysis. In H. Lutkepohl \& M. Kratzig (Eds.), Applied Time Series Econometrics. New York: Cambridge University Press.

Lutkepohl, H., Saikkonen, P., \& Trenkler, C. (2003). Comparison of tests for the cointegrating rank of a VAR process with a structural shift. Journal of Econometrics, 13, 201-229.

Ma, C. K., \& Kao, G. W. (1990). On exchange rate changes and stock price reactions. Journal of Business Finance and Accounting, 17(2), 441-449.

Pan, M.-S., Fok, R. C.-W. \& Liu, Y. A. (2007). Dynamic linkages between exchange rates and stock prices: Evidence from East Asian markets. International Review of Economics and Finance, 16, 503-520.

Perron, P. (1989). The great crash, the oil price shock and the unit root hypothesis. Econometrica, 57, 1361-1401.

Phillips, P. C. B., \& Perron, P. (1988). Testing for a unit root in times series regression. Biometrica, 75, 335-446.

Phylaktis, K., \& Ravazzolo, F. (2005). Stock prices and exchange rate dynamic. Journal of International Money and Finance, 24, 1031-1051.

Saikkonen, P., \& Lutkepohl, H. (2000). Testing for the cointegrating rank of a VAR process with a structural shift. Journal of Business and Economic Statistics, 18, 451-464.

Saikkonen, P., \& Lutkepohl, H. (2002). Testing for a unit root in a time series with a level shift at unknown time. Econometric Theory, 18, 313-348.

Sarmidi, T., \& Mohd Nor, A. H. S. (2001). Keberkesanan dasar kadar pertukaran tetap dalam mengkesampingkan faktor luar di BSKL. Jurnal Pengurusan, 20, 47-67. 
Seonen, L. A., \& Hennigar, E. S. (1988). An analysis of exchange rates and stock prices: The U.S. experience between 1980 and 1986. Akron Business and Economic Review, 19(4), 71-76.

Solnik, B., \& McLeavey, D. (2009). Global investments (6th ed.). Boston: Pearson-Prentice Hall.

Solnik, B. (1987). Using financial prices to test exchange rate models: A note. Journal of Finance, 42(1), 141-149.

Toda, H. Y., \& Yamamoto, T. (1995). Statistical inference in vector autoregressions with possibly integrated processes. Journal of Econometrics, 66, 225-250.

Trenkler, C. (2002). Testing for the Cointegrating Rank in the Presence of Level Shifts. Aachen: Shaker Verlag.

$\mathrm{Wu}, \mathrm{Y}$. (2000). Stock prices and exchange rates in a VEC model: The case of Singapore in the 1990s. Journal of Economics and Finance, 24(3), 260-274.

$\mathrm{Wu}, \mathrm{Y}$. (2001). Exchange rates, stock prices, and money markets: Evidence from Singapore. Journal of Asian Economics, 12, 445-458.

Yau, H.-Y., \& Nieh, C.-C. (2009). Testing for cointegration with threshold effect between stock prices and exchange rates in Japan and Taiwan. Japan and the World Economy, 21, 292-300.

Zhao, H. (2010). Dynamic relationship between exchange rate and stock price: Evidence from China. Research in International Business and Finance, 24, 103-112. 